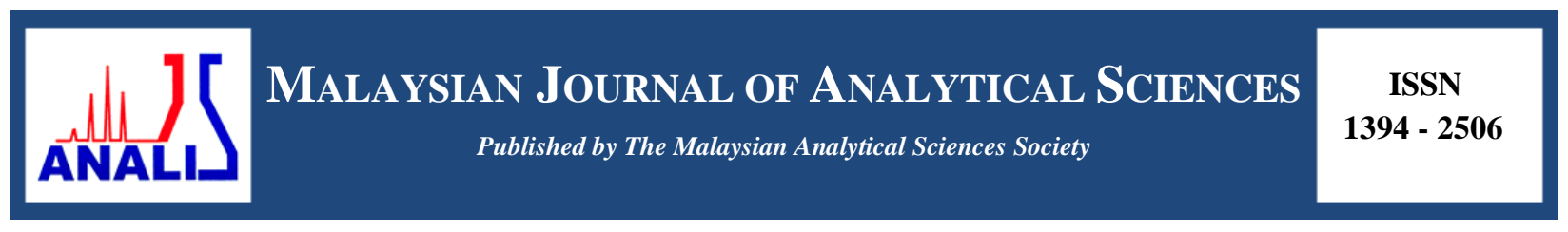

\title{
FABRICATION OF CELLULOSE MICROSPHERES FROM MODIFIED COTTON LINTER AND OIL PALM TRUNK FIBRE VIA EMULSION METHOD
}

\author{
(Fabrikasi Mikrosfera Selulosa daripada Linter Kapas dan Gentian Batang Kelapa Sawit \\ Termodifikasi Melalui Kaedah Emulsi)
}

Balqis Az-Zahraa Norizan ${ }^{1}$, Nurul Shuhadah Mahadi ${ }^{1}$, Nurul Nazatulatika Mohd Nizam ${ }^{1}$, Sarani Zakaria ${ }^{1}$, Muhammad Fauzi Daud ${ }^{2}$, Sharifah Nabihah Syed Jaafar ${ }^{1 *}$

${ }^{I}$ School of Applied Physics, Faculty of Science and Technology, Universiti Kebangsaan Malaysia, 43600 UKM Bangi, Selangor, Malaysia

${ }^{2}$ Institute of Medical Science Technology,

Universiti Kuala Lumpur Malaysia, 43000 Kajang, Selangor, Malaysia

*Corresponding author: nabihah@ukm.edu.my

Received: 20 July 2017; Accepted: 28 April 2018

\begin{abstract}
In this study, cellulose microspheres from modified cotton linter (CL) and oil palm trunk fibre (OPTF) were fabricated by using simple emulsion method. The cellulose was obtained from the CL and OPTF through the alkaline pre-treatment and acid hydrolysis processes. The emulsion method was performed using polyvinyl alcohol (PVA) as an emulsifying agent. The characterization of the cellulose from CL and OPTF were analysed using Fourier transform infrared spectroscopy (FTIR) and $\mathrm{X}$-ray diffraction (XRD), and the morphological characterizations of cellulose microspheres were later observed under optical microscopy $(\mathrm{OM})$ and field emission-scanning electron microscopy (FE-SEM). Based on the results, FTIR spectra displayed the lignin and hemicellulose had removed after treatments, while XRD revealed that the crystallinity index of OPTF and CL was increased after the treatments. The microspheres, formed with different ranges of size between 80 to $150 \mu \mathrm{m}$ under OM and FESEM, showed the formation of pores on the surface of the microspheres.
\end{abstract}

Keywords: emulsification, lignin, porous, field emission scanning electron microscopy

\section{Abstrak}

Kajian ini dijalankan bagi menghasilkan mikrosfera selulosa daripada linter kapas (LK) dan gentian batang kelapa sawit (GBKS) melalui kaedah emulsi. Selulosa didapati daripada LK dan gentian GBKS selepas proses pra-rawatan alkali dan hidrolisis asid. Manakala, kaedah emulsi dijalankan dengan menggunakan polivinil alkohol (PVA) sebagai agen pengemulsi. Pencirian selulosa daripada LK dan GBKS akan dianalisa menggunakan analisis transformasi inframerah Fourier (FTIR) dan pembelauan sinar-X (XRD) dan pencirian morfologi bagi mikrosfera selulosa dijalankan oleh mikroskopi optik (OM) dan mikroskop elektronimbasan pancaran medan (FE-SEM). Berdasarkan keputusan FTIR yang diperoleh, lignin dan hemiselulosa telah berjaya dibuang selepas rawatan, sementara itu, keputusan XRD menunjukkan terdapat peningkatan pada indeks kehabluran bagi GBKS dan LK selepas rawatan. Mikrosfera yang terbentuk juga dapat diperhatikan melalui OM dengan saiz berjulat 80 hingga $150 \mu \mathrm{m}$ dan FE-SEM pula menunjukkan penghasilan liang pada permukaan kedua-dua mikrosfera.

Kata kunci: pengemulsi, lignin, berliang, mikroskop elektron imbasan pancaran medan 


\section{Az-Zahraa et al: FABRICATION OF CELLULOSE MICROSPHERES FROM MODIFIED COTTON LINTER AND OIL PALM TRUNK FIBRE VIA EMULSION METHOD}

\section{Introduction}

Microspheres are mostly produced from polymers and ceramics such as poly(D,L, -lactide-co-glycolide) (PLG), poly(e-caprolactone) (PCL), poly(lactic-co-glycolic acid) (PLGA), calcium phosphate, and hydroxyapatite (HA) [1]. Today, the number of medical applications for natural and synthetic biomaterial continues to expand. The material selection is important due to their chemical, physical, and geometrical effects on the microcarriers. The porosity of the microspheres are one of the important properties needed in medical applications as porosity helps in cell proliferation, viability, and differentiation compared to non-porous microspheres. Furthermore, porous microspheres are preferred due to its high surface area, low density, low thermal conductivity, and good flow ability [2].

Cellulose and its derivatives are natural and low-cost polymer with renewable and biodegradable properties [3]. All of these properties make cellulose as one of the attractive materials in biomedical applications. For example, cellulose-based materials are excellent in prevention of excessive bleeding due to hemostatic agent, wound healing, implantation on connective tissue due to biocompatibility and long lasting stability [4]. As cellulose is known as the polymer with pores, it is suitable for the formation of porous microspheres.

The production of microspheres by thermal phase separation, emulsion polymerization, and spray drying possess a difficulty in maintaining the uniformity and homogeneity in particle size distribution. The most common technique in microspheres fabrication is emulsion method, where the polymer and the solvent are mixed together to appear in one phase under high speed rotation with the addition of emulsifier [5].

In Malaysia, oil palm trunk fibre (OPTF) has been underutilised, producing 8.2 million tonnes of waste annually [6]. Usually, the felled oil palm trunk (OPT) is used as compost or burned on the field. Consequently, carbon dioxide, carbon monoxide, and suspended particles of unburned carbon are released to the atmosphere which contributes to global warming and greenhouse effect. In this paper, the objective was to study the effect of microspheres microstructure on different modified cellulose (cotton linter (CL) and OPTF) by using emulsion method. Perhaps, the OPTF has a potential to be used as starting materials in microspheres fabrication.

\section{Materials}

\section{Materials and Methods}

Oil palm trunk fibre (OPTF) was provided by Leong Brothers Earthworks Construction, Kluang, Johor while cotton linter (CL) was purchased from Hubei Chemical Fibre, ammonium hydroxide $\left(\mathrm{NH}_{4} \mathrm{OH}\right)(28 \%-30 \%)$, hydrochloric acid ( $\mathrm{HCl})(36 \%-38 \%)$, sulphuric acid $\left(\mathrm{H}_{2} \mathrm{SO}_{4}\right)(95 \%-98 \%)$, dichloromethane (DCM) $(89.34 \mathrm{~g} / \mathrm{mol})$, and polyvinyl alcohol (PVA) (87\%-89\%), acetone (99.9\%) were purchased from Sigma-Aldrich.

\section{Preparation of cellulose from CL and OPTF}

The $\mathrm{CL}$ was ground and dissolved in $0.5 \% \mathrm{HCl}$ at a ratio of $1: 2(\mathrm{w} / \mathrm{v})$ for 4 hours at $120^{\circ} \mathrm{C}$. Then, the hydrolyzed $\mathrm{CL}$ was filtered and washed until pH became neutral and dried in an oven for 24 hours at $60^{\circ} \mathrm{C}$. OPTF was washed to remove dust and dried in oven for 24 hours at $60^{\circ} \mathrm{C}$. The OPTF was then ground to form powder. $100 \mathrm{~g}$ of OPTF powder was dissolved in $1 \mathrm{~L} 10 \% \mathrm{NH}_{4} \mathrm{OH}$ to remove lignin for 24 hours at $25^{\circ} \mathrm{C}$. After lignin was removed, the remaining solid was hydrolyzed by $0.5 \% \mathrm{HCl}$ at $120{ }^{\circ} \mathrm{C}$ for 4 hours. The hydrolyzed powder was filtered and washed until $\mathrm{pH}$ became neutral and dried in an oven for 24 hours at $60^{\circ} \mathrm{C}$.

\section{Preparation of cellulose microspheres $(\mathbf{C M})$}

Cellulose microspheres $(\mathrm{CM})$ were prepared by undergoing emulsion method, where $0.002 \mathrm{~g}$ cellulose powder from OPTF and CL were dissolved in $2 \mathrm{~mL} \mathrm{DCM}$ for $30 \mathrm{~s} .50 \mathrm{~mL}$ of $5 \%$ PVA $\left(10^{\circ} \mathrm{C}\right)$ was added to the mixture and stirred for 2 hours at $500 \mathrm{rpm}$. The emulsion was then subjected to another $500 \mathrm{~mL}$ of $1 \%$ PVA $\left(10^{\circ} \mathrm{C}\right)$ and stirred for 6 hours at $500 \mathrm{rpm}$. Lastly, the microspheres produced were dried under ambient conditions. The microspheres were kept in a dry box prior to analyses.

\section{Characterization: X-ray diffraction (XRD)}

Phase and crystallinity index (CrI) of cellulose samples were characterized using X-ray diffraction (XRD) (Bruker D8 Advance Madison, WI, USA). The XRD was performed using radiation of $\mathrm{Cu} \mathrm{K \alpha}=1.5458 \AA$ at a diffraction angle (20) range from 10 to $80^{\circ}$. Diffraction profiles were carried out with a Gaussian function to determine the $\mathrm{CrI}$ 
of the samples. The CrI of the samples were examined by using Bruker Advanced X-Ray Solutions software, DIFFRAC ${ }^{P L U S}$ Evaluation (EVA) with the following equation 1 with slight modifications:

$$
\mathrm{CrI}(\%)=A_{\text {Cystal }} / A_{\text {Total }} \times 100
$$

where $A_{\text {Crystal }}$ is the sum of the areas under the crystalline diffraction peaks and $A_{\text {Total }}$ represents the total area under the diffraction curve between $2 \theta=10^{\circ}-80^{\circ}$.

\section{Fourier transform infrared spectroscopy}

The FTIR spectra of $3 \mathrm{mg}$ CL and OPTF cellulose were recorded using Fourier transform infrared spectroscopy (FTIR) spectrometer (Perkin Elmer Spectrum 400) to observe the functional groups before and after chemical treatments. The transmittance mode and $16 \mathrm{~s} \mathrm{scanning} \mathrm{number} \mathrm{were} \mathrm{selected} \mathrm{ranging} \mathrm{from} 4000 \mathrm{~cm}^{-1}$ to $600 \mathrm{~cm}^{-1}$.

\section{Optical microscope (OM)}

The size and distribution of CM was analysed by optical microscope (OM) (Axiolab A1.MAT). A small sample was dispersed in water and placed between two glass slides and then observed under OM. The dimensions of CM were determined using digital image analyses with 10x magnifications.

\section{Field emission scanning electron microscope (FE-SEM)}

The morphology of CM from CL and OPTF cellulose were observed by using field emission scanning electron microscope (FE-SEM, Zeiss/Supra 55VP). Platinum was used to coat all samples in order to enhance the quality of images and prevent charging with 10x magnification at $1.0 \mathrm{kV}$.

\section{Crystallinity analysis of cellulose from $C L$ and OPTF}

\section{Results and Discussion}

XRD diffractogram of OPTF, modified OPTF, CL and modified CL were observed in Figure 1. The spectra shows the changes happened in diffraction pattern of OPTF and CL after undergoing the chemical treatments. The peak intensity (Figure 1) which was observed at $2 \theta=15^{\circ}, 16^{\circ}, 22^{\circ}$, and $35^{\circ}$ confirmed the modified cellulose was type I [7]. Moreover, the peaks corresponded to the crystallographic planes of 110, 11 0 , 200, and 004, respectively. This result was comparable to Lamaming et al. [8] for OPTF and for CL [9]. The CrI of $22.4 \%, 33.2 \%, 61.8 \%$, and $60.8 \%$ were determined for OPTF, modified OPTF, CL and modified CL, respectively. Based on the findings, $\mathrm{CrI}$ of OPTF was lower as compared to CL due to high number of extractives and thick wall owned by OPTF which gives strength to the plant [10]. In addition, the CrI result for the CL suggested that there was no adverse effect of acid hydrolysis on crystalline structure of CL, whereas the CrI of OPTF greatly increased after the hydrolysis due to the elimination of amorphous substances such as hemicellulose and lignin [11].

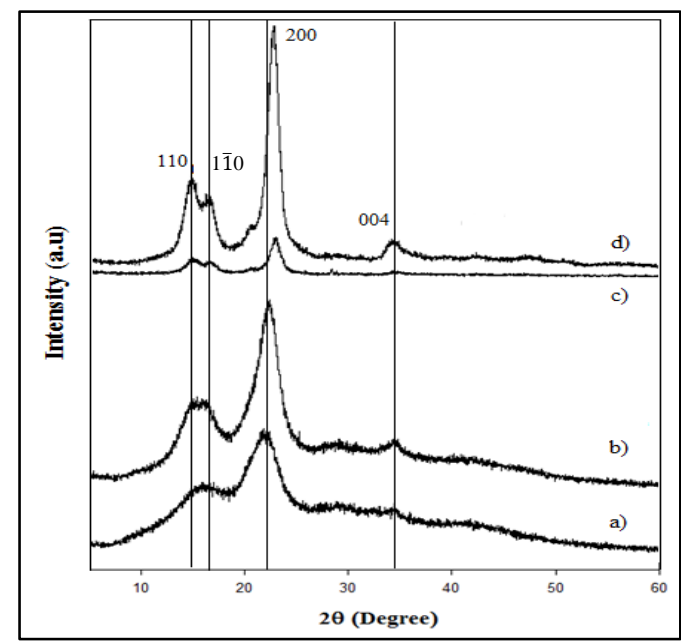

Figure 1. X-ray diffraction spectra of (a) OPTF, (b) modified OPTF, (c) CL, and (d) modified CL 


\section{Az-Zahraa et al: FABRICATION OF CELLULOSE MICROSPHERES FROM MODIFIED COTTON LINTER AND OIL PALM TRUNK FIBRE VIA EMULSION METHOD}

\section{Spectroscopic analysis}

Figure 2 represents the FTIR spectra of OPTF, modified OPTF, CL and modified CL. Basically, the spectra look alike with slight differences on the intensity of certain peaks. All spectra showed a peak at $\sim 3400 \mathrm{~cm}^{-1}$. According to Salim and Sorya [12], the stretching vibration of O-H performed at $3200 \mathrm{~cm}^{-1}$ to $3700 \mathrm{~cm}^{-1}$ was due to the lignocellulosic materials in the fibre, consisting of hemicellulose and cellulose. From the spectra, all samples appeared peaks at $2800 \mathrm{~cm}^{-1}$ to $2900 \mathrm{~cm}^{-1}$ which contributed to $\mathrm{C}-\mathrm{H}$ stretching vibrations. Meanwhile, the absorption of water by cellulose can be indicated by a peak at $1500 \mathrm{~cm}^{-1}$ to $1600 \mathrm{~cm}^{-1}$ [13]. The difference of certain peaks can be seen between spectra of CL and OPTF. Peaks at $1000 \mathrm{~cm}^{-1}$ to $1100 \mathrm{~cm}^{-1}$ which corresponded to the deformation of $\mathrm{C}-\mathrm{H}$ in cellulose were observed less prominent on OPTF as compared to CL due to the removal of lignin and hemicellulose [14].

Besides that, the effect of treatment on OPTF had caused the absence of peak at $\sim 1700 \mathrm{~cm}^{-1}$ on modified OPTF which fit to the elimination of hemicellulose on the samples [15]. The peaks at $\sim 1200 \mathrm{~cm}^{-1}$ on the spectra which correlated with the $\mathrm{C}=\mathrm{O}$ bonding in lignin could be observed at OPTF but changed slightly after chemical treatment on modified OPTF [16], but no indication on CL samples due to high crystallinity. Another peak at $800 \mathrm{~cm}^{-1}$ to $900 \mathrm{~cm}^{-1}$ was appointed as amorphous region on the samples [17].

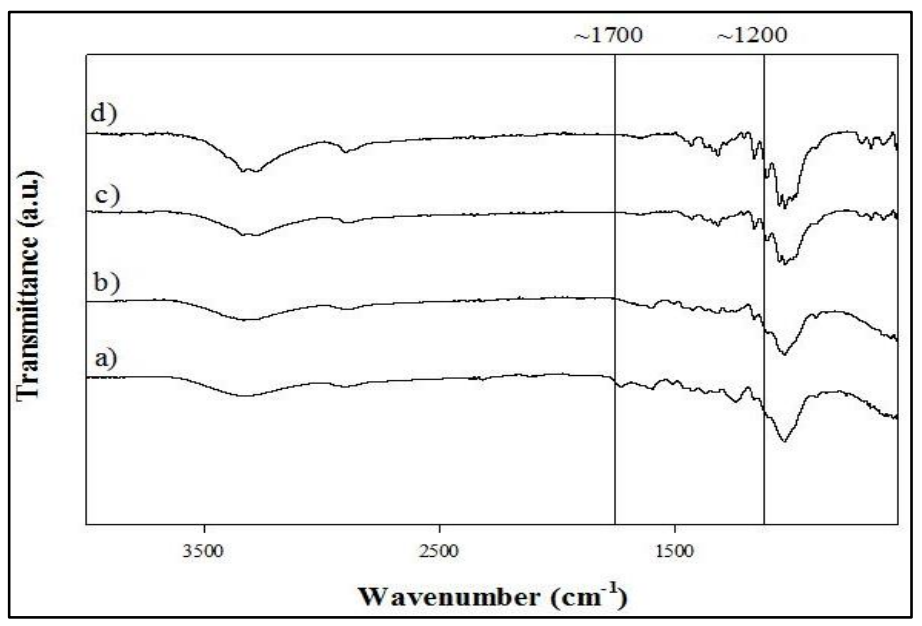

Figure 2. FTIR spectra of (a) OPTF, (b) modified OPTF, (c) CL, and (d) modified CL

\section{Microstructural analysis}

Based on Figure 3, spherical shape of CM shows size of 80 to $150 \mu \mathrm{m}$ in diameter for CL and OPTF microspheres. The result also showed that the CL microspheres exhibited smaller size as compared to OPTF microspheres. This might be due to the high crystalline region of $\mathrm{CL}$ which contributed to more hydrogen bond networks that made cellulose rigid and resistant to solvent and emulsifier reactions than OPTF. Furthermore, difference in size of the microspheres could be related to the stability of the emulsion in the solution. According to Mi et al. [18], the stability of the emulsion was related to the interface energy between the polymer and the emulsifier. Flocculation between the microspheres can be avoided by reducing the interface energy. Besides that, different sizes of microspheres also resulted from the increasing temperature as the solution was stirred for 6 hours after addition of emulsifier. This resulted in increase of temperature which gave effect to the interfacial strength of emulsion where the interfacial strength reduced and destabilised the emulsion, hence causing flocculation [19]. 

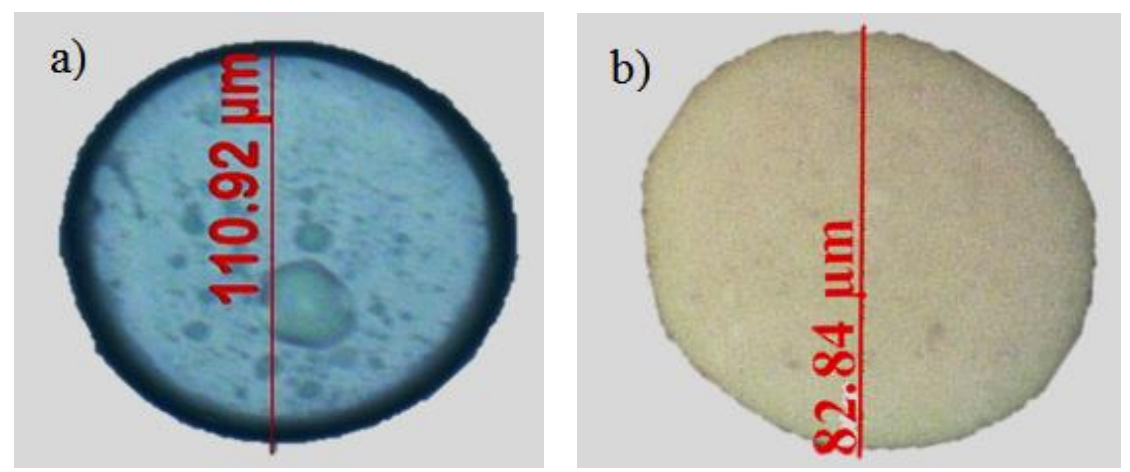

Figure 3. Optical micrographs of cellulose microspheres fabricated from (a) modified OPTF and (b) modified CL

\section{Surface morphology analysis}

Figure 4 shows a formation of porous structure on the surface of microspheres. The pores were formed due to the complete evaporation of solvent that occurred during processing [20]. Besides, the solvent used in this research, i.e., DCM has low solubility towards the water, thus prevents the water to penetrate into the droplet hence supresses the pore formation. This property favours the microspheres to be used as carriers due to the pores that provide maximum surface area for the attachment of substances. In addition, the diameter of the pores $<20 \mu \mathrm{m}$ was said to be ideal as carriers [21].
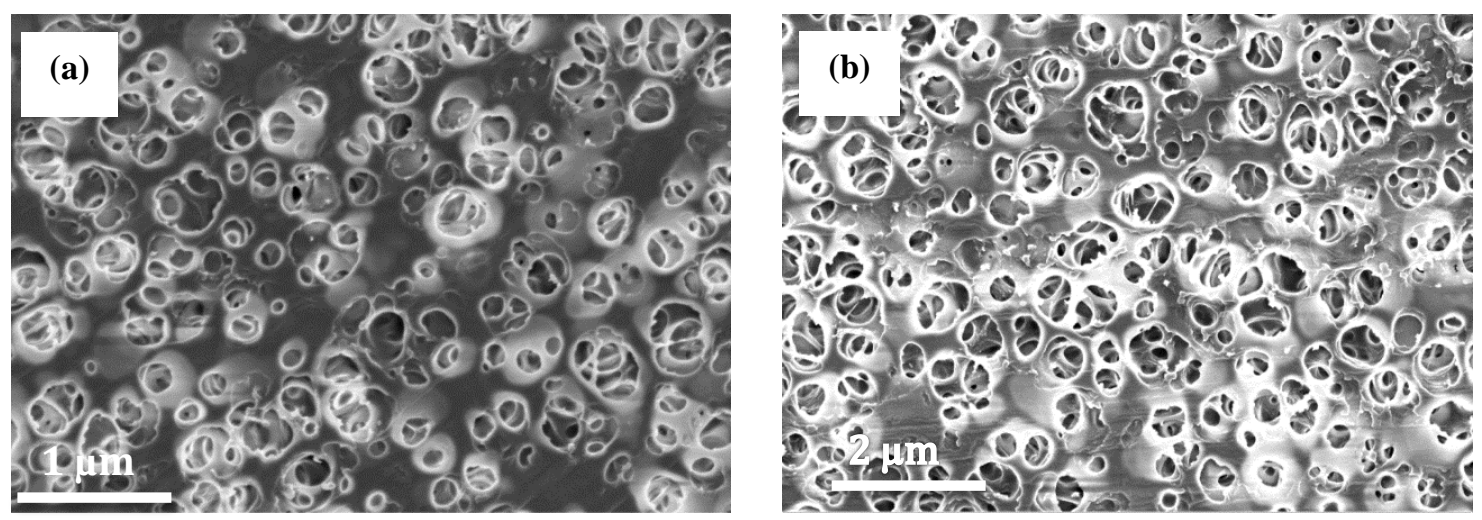

Figure 4. Pore size of cellulose microspheres from (a) modified OPTF and (b) modified CL

\section{Conclusion}

In conclusion, cellulose microspheres from modified OPTF and CL were successfully prepared using emulsion method. The microspheres from CL and OPTF revealed the size of 80 to $150 \mu \mathrm{m}$ in diameter and showed a porous structure. The FTIR spectra displayed that non-cellulosic components were removed after treatments, while XRD revealed that there was an increase in crystallinity index after treatment, which were $22.4 \%, 33.2 \%, 61.8 \%$, and $60.8 \%$ for OPTF, modified OPTF, CL and modified CL, respectively.

\section{Acknowledgement}

We would like to acknowledge the financial support from the Industrial and Malaysian Ministry of Higher Education through the GUP-2017-114, LRGS/TD/2012/USM-UKM/PT/04, and Centre for Research and Instrumentation (CRIM), UKM for the testing services. 


\section{References}

1. Xiao, Q., Zhou, K., Chen, C., Jiang, M., Zhang, Y., Luo, H. and Zhang, D. (2016). Hollow and porous hydroxyapatite microspheres prepared with an $\mathrm{O} / \mathrm{W}$ emulsion by spray freezing method. Materials Science \& Engineering C, 69: 1068-1674.

2. Yang, H., Xie, Y., Hao, G., Cai, W. and Guo, X. (2015). Preparation of porous alumina microspheres via n oilin-water emulsion method accompanied by a sol-gel process. New Journal of Chemistry, 40: 589-595.

3. Dong, S., Bortner, M. J. and Roman, M. (2016). Analysis of the sulfuric acid hydrolysis of wood pulp for cellulose nanocrystal production: a central composite design study. Industrial Crops and Products, 93: 76-87.

4. Czaja, W. K., Young, D. J., Kawecki, M. and Jr., R. M. (2007). The future prospects of microbial cellulose in biomedical applications. Biomacromolecules, 8: 1-12.

5. Kemala, T., Budianto, E. and Soegiyono, B. (2012). preparation and characterization of microspheres based on blend of poly(lactic acid) and poly(E-caprolactone) with poly(vinyl alcohol) as emulsifier. Arabian Journal of Chemistry, 5: 103-108.

6. Suhaily, S. S., Jawaid, M., Abdul Khalil, H., Mohamed, A. and Ibrahim, F. (2012). A review of oil palm biocomposites for furniture design and applications: potential and challenges. BioResources, 7(3): 4400-4423.

7. Tang, Y., Shen, X., Zhang, J., Guo, D., Kong, F. and Zhang, N. (2015). Extraction of cellulose nano-crystals from old corrugated container fibre using phosphoric acid and enzymatic hydrolysis followed by sonication. Carbohydrate Polymers, 125: 360-366.

8. Lamaming, J., Hashim, R., Sulaiman, O., Leh, C. P., Sugimoto, T. and Nordin, N. A. (2015). Cellulose nanocrystals isolated from oil palm trunk. Carbohydrate Polymers, 127: 202-208.

9. Gan, S., Padzil, F. N. M., Zakaria, S., Chia, C. H., Jaafar, S. N. S. and Chen, R. S. (2015). Synthesis of liquid hot water cotton linter to prepare cellulose membrane using NaOH/Urea or LiOH/Urea. BioResources, 10: 2244-255.

10. Lamaming, J., Hashim, R., Leh, C. P., Sulaiman, O., Sugimoto, T. and Nasir, M. (2015). Isolation and characterization of cellulose nanocrystals from parenchyma and vascular bundle of oil palm trunk (Elaeis Guineensis). Carbohydrate Polymers, 134: 534-540.

11. Ramli, R., Junadi, N., Beg, M. D. and Yunus, R. M. (2015). Microcrystalline cellulose (MCC) from oil palm empty fruit bunch (EFB) fibre via simultaneous ultrasonic and alkali treatment. International Journal of Chemical, Nuclear, Materials and Metallurgical Engineering, 9: 8-11.

12. Salim, B. and Sorya, N. (2015). Effects of chemical treatments on the structural, mechanical and morphological properties of poly(vinylchloride)/spartium junceum fibre composites. Cellulose Chemistry and Technology, 49: 375-385.

13. Rhim, J.-W., Reddy, J. P. and Luo, X. (2014). Isolation of cellulose nanocrystals from onion skin and their utilization for the preparation of agar-based bio-nano composites films. Cellulose, 22: 407-420.

14. Mohamad Haafiz, M., Hassan, A., Zakaria, Z. and Inuwa, I. (2014). Isolation and characterization of cellulose nanowhiskers from oil palm biomass microcrystalline cellulose. Carbohydrate Polymers, 103: 119-125.

15. Nazir, M. S., Wahjoedi, B. A., Yussof, A. W. and Abdullah, M. A. (2013). Eco-friendly extraction and characterization of cellulose from oil palm empty fruit bunches. BioResources, 8: 2161-2172.

16. Owolabi, A. F., Mohamad Haafiz, M., Hossain, M. S., Hussin, M. H. and Nurul Fazita, M. (2017). Influence of alkaline hydrogen peroxide pre-hydrolysis on the isolation of microcrystalline cellulose from oil palm fronds. International Journal of Biological Macromolecules, 95: 1228-1234.

17. Lamaming, J., Hashim, R., Leh, C. P. and Sulaiman, O. (2017). Properties of cellulose nanocrystals from oil palm trunk isolated by total chlorine free method. Carbohydrate Polymers, 156: 409-416.

18. Mi, Y., Li, J., Zhou, W., Zhang, R., Ma, G. and Su, Z. (2016). Improved stability of emulsions in preparation of uniform small-sized konjac glucomanna (KGM) microspheres with epoxy-based polymer membrane by premix membrane emulsification. Polymers, 8: 1-13.

19. Parida, P., Mishra, S. C., Sahoo, S., Behera, A. and Nayak, B. P. (2016). Development and characterization of ethylcellulose based microspheres for sustained release of nifedipine. Journal of Pharmaceutical Analysis, 6: 341-344.

20. Murakami, M., Matsumoto, A., Watanabe, C., Kurumado, Y. and Takama, M. (2015). Fabrication of porous ethyl cellulose microspheres based on the acetone-glycerin-water ternary system: Controlling porosity via the solvent-removal mode. Drug Discoveries \& Therapeutics, 9: 303-309. 
21. Qutachi, O., Vetsch, J., Gill, D., Cox, H., Scurr, D. and Hofmann, S. (2014). Injectable and porous PLGA microspheres that form highly porous scaffolds at body temperature. Acta Biomaterialia, 10: 5090-5098. 